\title{
Effect of Different Budding Methods and Timings on Budding Success of Chestnut (Castanea sativa, Mill)
}

\author{
Sharbat Hussain ${ }^{1}$, Rifat Bhat ${ }^{1}$, M.M. Mir ${ }^{1}$, Sheeraz A. Wani ${ }^{2}$, \\ Rahila Shameem $^{1}$ and Mohit Husain ${ }^{3 *}$ \\ ${ }^{1}$ Division of Fruit science, Sher-e-Kashmir University of Agricultural Sciences and \\ Technology of Kashmir-190025, J\&K, India \\ ${ }^{2}$ Division of Agronomy, Sher-e-Kashmir University of Agricultural Sciences and Technology \\ of Kashmir-190025, J\&K, India \\ ${ }^{3}$ Faculty of Forestry, Sher-e-Kashmir University of Agricultural Sciences and Technology of \\ Kashmir-190025, J\&K India \\ *Corresponding author
}

\begin{tabular}{|c|c|}
\hline & B S T R A T \\
\hline Keywords & \multirow{3}{*}{$\begin{array}{l}\text { The present experiment was carried out at Division of Fruit Science SKUAST-K Shalimar } \\
\text { during the year } 2014 \text { under open field conditions. Two budding methods viz T and chip } \\
\text { budding performed at four different timings }\left(3^{\text {rd }} \text { week of July, } 1^{\text {st }} \text { and } 3^{\text {rd }} \text { week of August }\right. \\
\text { and } 1^{\text {st }} \text { week of September) were evaluated. T-budding was found significantly superior } \\
\text { over chip with highest bud take }(74.12 \%) \text {, budding success }(65 \%) \text {, bud sprouting } \\
(68.53 \%) \text {, shoot length }(37.01 \mathrm{~cm}) \text {, shoot diameter }(6.10 \mathrm{~mm}) \text {, leaf number per plant } \\
(22.91) \text {. Among the timings performed on } 3^{\text {rd }} \text { week of July was found significantly } \\
\text { superior in case of T-budding in which highest budding success }(73.33 \%) \text {, shoot length } \\
(48.17 \mathrm{~cm}) \text {, shoot diameter }(6.68 \mathrm{~mm}) \text {, leaf number per plant }(37.90) \text { were recorded. } \\
\text { However in case of chip budding, I } \mathrm{I}^{\text {st }} \text { week of August recorded highest budding success } \\
(70.33 \%) \text {, shoot length }(46.08 \mathrm{~cm}) \text { and shoot diameter }(8.20 \mathrm{~mm}) \text {. The interaction between } \\
\text { time and method of budding showed significant difference between the various treatment } \\
\text { combinations tried. }\end{array}$} \\
\hline Artic & \\
\hline & \\
\hline
\end{tabular}

\section{Introduction}

Chestnut (Castanea sativa Mill.) tree, native of the northern hemisphere especially China, Korea, Japan and South Europe, has attracted human attention due to its great economic value, nutritious fragrant, tasty nuts and valuable timber wood, besides being an important component of agro forestry systems (Janick and Moore, 1975). Chestnut has attracted huge attention in the last few decades owing to its multi-nutritional benefits. The popularity of chestnut is attributed due to its high productivity, ease of harvesting, simplicity of preparation for eating, low fat content, no cholesterol and diversity of uses for high and low income people (Woodroof, 1979). It is the only nut that contains vitamin $\mathrm{C}$ of about $40 \mathrm{mg}$ per $100 \mathrm{~g}$ of raw product. In India it is grown throughout the Himalayas up to Assam and Meghalaya at an altitude of 2,000 to 3,000 masl (Amardeep, 2008). The important chestnut producing states in India are Jammu and Kashmir, Himachal Pradesh 
and the north-western parts of Uttar Pradesh (Anonymous, 1992). In Jammu and Kashmir the profile of fruit industry has been all along dominated by apple, however, few chestnut orchards were established by State Horticulture production department in few areas of Srinagar (Harwan), Anantnag and Budgam for public interest (Anonymous, 2011). Chestnut is cold hardy, drought resistant and can withstand temperature as low as $-25^{\circ} \mathrm{C}$ when dormant. Different propagation techniques like rootings, cuttings, micropropagation, layering have been tried in different parts of world but with little success (Celik et al., 2009). However, grafting and budding have shown promising results (Serdar and Demirsoy, 2010). It has been reported that the most economical and practical vegetative method for chestnut is grafting and budding (Saylu, 1984). Different grafting and budding methods can be used in chestnut depending upon many factors such as time of grafting, budding, age and growth, vigour of rootstock, skilled knowledge, quality and quantity of scion wood (Ferrini, 1993). In order to encourage nut growers towards chestnut cultivation, it is important to provide them quality plant material. Since no systematic work has been done so far, regarding standardization of propagation techniques in chestnut under agroclimatic condition of Kashmir valley. Therefore, an attempt was made to study the performance of different budding methods of chestnut with different time

\section{Materials and Methods}

An experiment entitled "on the effect of different budding methods and time on budding success of chestnut (Castanea sativa Mill.)" was carried out at Experimental Farm of Division of Fruit science, Sher-e-Kashmir University of Agricultural Sciences and Technology, Shalimar Campus (J\&K) during 2014. The experimental site is located at an elevation of 1,587 $\mathrm{m}$ above mean sea level and situated at $34^{\circ} 08^{\prime}$ North latitude and $74^{\circ} 08^{\prime}$ East longitude. The study was carried out under open field conditions with two different methods of budding ( $\mathrm{T}$ and Chip budding) performed at 4 different timings $\left(3^{\text {rd }}\right.$ week of July, 1 st and $3^{\text {rd }}$ week of August and $1^{\text {st }}$ week of September). One year old seedlings raised from thick shelled nuts were used as rootstocks in the study. The seedling rootstocks of $1-1.5 \mathrm{~cm}$ thickness were utilized for the purpose Generally 4 inch portion of the root stock from the ground surface was kept clean and smooth for performing budding. Healthy bud sticks of uniform growth from current season shoot were selected for budding purposes. The experimental was laid in Randomized Complete Block Design (RCBD) with four replications (where in 10 budded plants constitute one replication of a treatment). The observations were recorded on bud bursting/leafing out, average shoot length, number of leaves/shoot, leaf area/ shoot and budding success (\%). The data was analyzed using the statistical programme OP STAT.

\section{Results and Discussion}

\section{Bud take (\%)}

Among the two budding methods and different timings tried T-budding recorded significantly superior bud take $(74.16 \%)$ compared to chip budding $(68.33 \%)$. This might be due to the fact that complete union of xylem and cambium tissue of the scion and root stock match much closer that helps in callus tissue differentiation into new cambium tissue. The less bud take in the chip budding is probably due to excessive bleeding in early budding timing results in poor union formation and desiccation of buds. High humidity (good for callus formation), optimum temperature (helps in new parenchymatous callus proliferation between stock and scion) and good sap flow results in better budding success. These results 
were in agreement with the findings Hartmann and Kester (1997), Serdar and Soylu, (2005), Warmund and Coggeshall (2009) this indicated that $\mathrm{T}$ budding was significantly superior over chip budding. Observations on bud take in relation to different budding timing revealed that maximum bud take was attained when $\mathrm{T}$ budding was done $3^{\text {rd }}$ week July $(83.33 \%)$ and lowest on $1^{\text {st }}$ of week September $(66.60 \%)$ and while in case of chip budding highest bud take was recorded on $1^{\text {st }}$ week of August $(73.33 \%)$ and lowest on $3^{\text {rd }}$ week of July $(60.0 \%)$. These results are in line with findings of Serdar and Soylu, 2005, who observed that $\mathrm{T}$ budding in July to August proved successful in terms of total bud take and bud sprouting. The maximum success of bud take and final budding success was obtained in the month of July. It may be due to high relative humidity and comparatively mature scion wood, while as, Pathak and Srivastava (1975) obtained 80 per cent of bud take and 60 to 70 per cent budding success during July to August.

\section{Bud sprout (\%)}

The observation on bud sprouting percentage was recorded in the month of April. In the present study, comparatively higher percentage of success was recorded in $\mathrm{T}$ budding 68.33 per cent compared to chip budding 62.50 per cent. This might be because of the formation of better graft union due to more contact of cambial layers of stock and scion and congenial weather and soil moisture conditions prevailing during the period after budding on $30^{\text {th }}$ July. These results are in close conformity with those reported by Stritzke (1959). Stritzke (1959) indicated that a constant temperature of $27{ }^{\circ} \mathrm{C}$ during the operation beds was the most important factor affecting the walnut grafts. Gautam et al., (1991), who reported the highest budburst (75\%) while practicing T-budding of peach on local peach root stocks. The low bud sprouting percentage in chip budding might be due to lower bud take percentage. These results were also in line with Warmund and Coggeshall (2009), whom obtained similar results in case of chestnut. Amongst different timing, highest bud sprouting percentage was recorded in $\mathrm{T}$ budding $(76.66 \%)$ performed in the $3^{\text {rd }}$ week of July over chip budding $(50.0 \%)$ than other timing. The significant superiority of $\mathrm{T}$ budding over the chip budding performed in other timing might be due to rapid sap flow in stock and scion favourable for the higher bud sprouting. In general, the period from $3^{\text {rd }}$ week of July to $3^{\text {rd }}$ week of August appears to be the most suitable time for performing budding operations in chestnut propagation. These results are in accordance with the findings of Akhter et al., (2000) and Jhoolka and Rindhe (2000). The interaction between budding method and timing showed significant effect with respect to sprouting percentage. Different methods of budding tried, gave different results in terms of bud sprouting at different timing. The results revealed that T-budding performed in the month of August registered maximum bud sprouting of 71.66 per cent. It was also observed that bud sprouting decreased from July to September in case of T-budding. It may be due to decrease in sap flow in plants with time and also due to decrease in temperature.

\section{Budding success (\%)}

There were significant variation in the success rate of the two budding methods namely $\mathrm{T}$ and chip budding. Significantly higher success was obtained with $\mathrm{T}$ budding $(65 \%)$ than chip budding $(57.50 \%)$. In the present study, comparatively higher percentage of success in $\mathrm{T}$ budding might be because of the formation of better graft union due to more contact of cambial layer of stock and scion, good sap flow and congenial weather and optimum soil moisture during $3^{\text {rd }}$ week of July and $1^{\text {st }}$ week of August. 
Table.1 Effect of budding methods and timing on bud-take percentage, bud sprout percentage, budding success percentage and total leaf number in chestnut

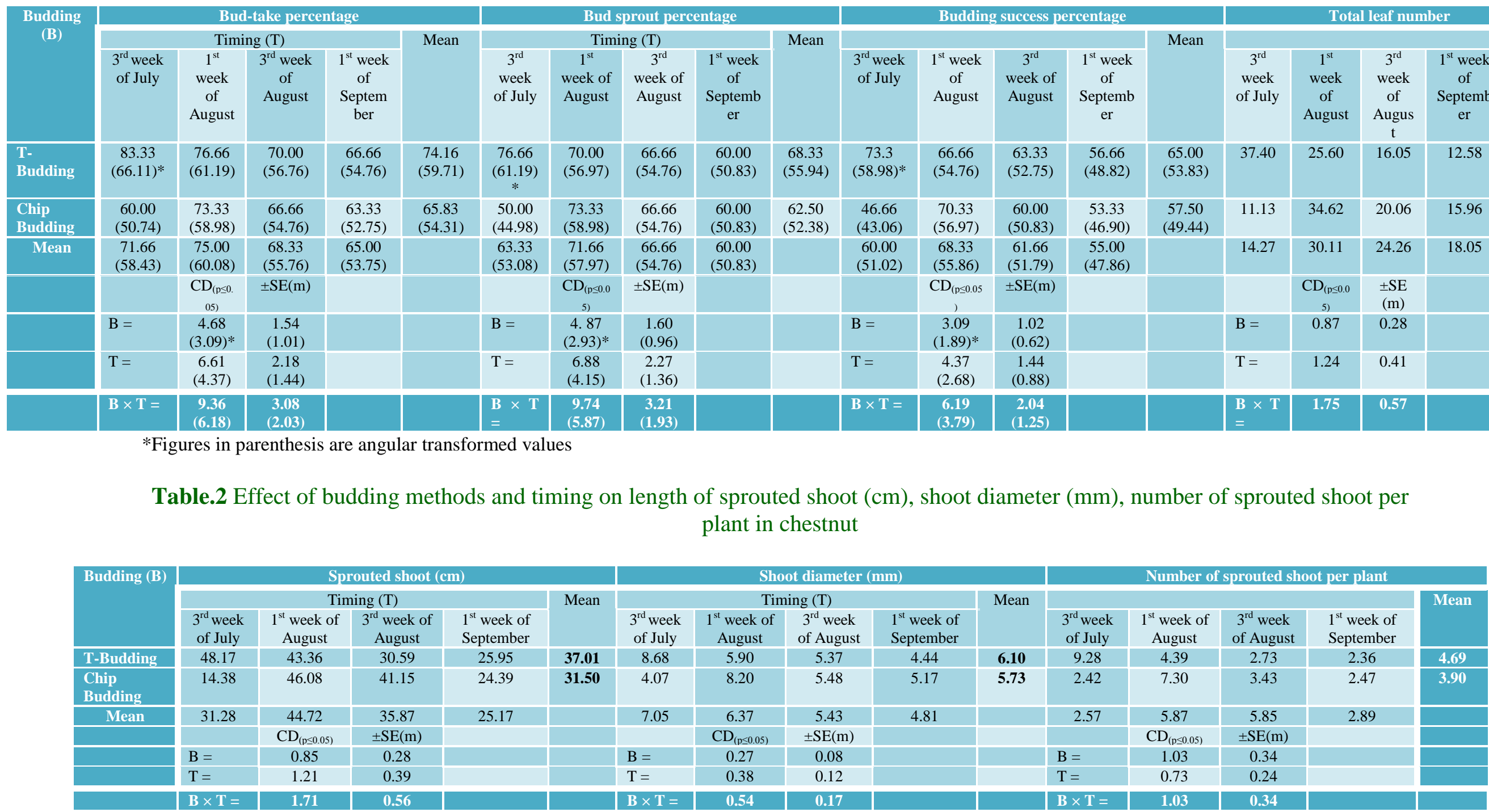

*Figures in parenthesis are angular transformed values 
These findings are in close conformity with those reported by Serdar and Soylu (2005) in case of T budding. Hartmann et al., (1990) also reported that $\mathrm{T}$ budding allows better drainage of excessive sap and bleed. While as Warmund and Coggeshall (2009), reported callus was produced around the bud plate on 75 per cent or more of the grafts in case of chip budding. However, the buds often failed to grow, especially at the early budding dates. The lowest success was reported on $1^{\text {st }}$ week of September $(55.0 \%)$. At earliest dates, tissue growth around the budding tape was excessive and sometimes covered the scion bud. While the greatest per cent bud take, budding success occurred on $1^{\text {st }}$ week of August is unknown if later grafting times would improve the success rate in case of chip budding by Warmund and Coggeshall (2009).

Irrespective of the budding methods employed, $1^{\text {st }}$ week of August budding with overall success of 68.33 per cent proved to be optimum time for budding chestnut. The higher success in July and August might be due to the rapid sap flow in stock and scion favourable for the higher bud take, bud sprout and budding success. The findings are in agreement with Warmund and Coggeshall (2009) and Celik et al., (2009).

\section{Shoot length $(\mathrm{cm})$}

The shoot length of the plants was maximum in T-budded $(37.01 \mathrm{~cm})$ plants and minimum in chip budded $(31.50 \mathrm{~cm})$ plants. Maximum growth of T-budded plants might be attributed to better graft union due to better contact of cambial layers of stock and scion, early completion of bud sprouting and initiation of subsequent growth. These results are in accordance with the results obtained by Celik et al., (2009) in case of chip budding. Serdar and Macit (2010) also reported better linear growth in T-budding as compared to patch budding. Among the different timing, budding performed during $1^{\text {st }}$ week of August showed significant superiority in scion length over the other budding timing. It must be due to early graft union formation and early sprouting in August budded plants. This may also be attributed to greater number of leaves, that elevated the rate of photosynthesis and hence availability of photosynthates for growth and development of composite plants. Maximum shoot length of $50.27 \mathrm{~cm}$ when patch budding was carried during mid-July in Guava. These results are also in accordance with the results drawn by Ahmad et al., (2012) in peach, who also reported maximum budding growth $(127.9 \mathrm{~cm})$ in the plants budded on ending July.

\section{Shoot diameter $(\mathrm{mm})$}

$\mathrm{T}$ budding showed significantly maximum shoot diameter (mm) over chip budding. Better growth of $\mathrm{T}$ budded plants may be attributed to the better graft union of cambium layers of stock and scion, more surface contact of scion with stock, maximum humidity and optimum temperature, early completion of bud sprouting and initiation of subsequent growth.

The lower periodical linear growth, of the plants budded in $4^{\text {th }}$ week of August and $1^{\text {st }}$ week of September to the plant budded in $3^{\text {rd }}$ week of July and $1^{\text {st }}$ week of August might be due to less sap flow, humidity and low temperature which act as a damper on the meristematic activity of the plant, resulting in lesser growth. The highest observed on $1^{\text {st }}$ week of August followed by $3^{\text {rd }}$ week of July might be due to the prevailing optimum temperature and humidity. Also during this period the cambial cells were actively dividing (Hartmann and Kestar, 1968) which might have resulted in early bud union and more subsequent growth of plants. Howard (1979) reported that the highest radial growth 
of plants with $\mathrm{T}$ budding could be attributed to greater uptake of nutrients and more uniform growth in $\mathrm{T}$ budding. The results also supported by the reports of Serdar and Soylu (2005) and Celik et al., (2009).

\section{Number of leaves}

Perusal of the data presented, reveals that the number of leaves per plant was maximum in T-budding (22.91) as compared to chip budding (20.44). The maximum number of leaves in T-budded plants might be due to higher shoot length attained by such plants. Among the different timing, maximum number of leaves were observed in August budded plants (30.11). It may be due to maximum number of branches and better growth of August budded plants which were earliest to sprout.

These results matched with the results drawn by Ozturk and Serdar (2011) in chestnut. Similar results are also obtained by Ahmad et al., (2012), who reported maximum number of leaves (29.20) on July budded plants in peach. Similar results were found by Akhter et al., (2000), who observed maximum number of leaves on plants budded in August. Interaction between budding method and time were significantly influenced by the number of leaves.

From the results of the present finding, it can be concluded that among the two methods of budding performed during the experiment, $\mathrm{T}$ budding showed better results over the chip budding. Also among the timing on which budding was carried out, $3^{\text {rd }}$ week of July was found to be the best timing for performing $T$ budding in chestnut. However, in case of chip budding the optimum timing was observed in $1^{\text {st }}$ week of August, after taking into consideration the bud take per cent, bud sprouting per cent, budding success and other characteristics.

\section{References}

Ahmad, I., Cheng, Z., Liu, T., Nan, W.C., Ejaz, M., Khan, A.K. and Wasila, H. 2012. Effect of different time of budding on the bud take success of peach on peach rootstock. Advances in Environmental Biology, 6(5): 18481852.

Akhtar, I., Hussain, S.A. and Nawab, A. 2000. Effect of different time of budding of apricot on peach rootstock. Sarhad Journal of Agriculture 16(2): 163-165.

Amardeep, K. 2008. Survey and selection of promising chestnuts in district Srinagar. M.Sc. Thesis submitted to Sher-eKashmir University of Agriculture Science and Technology of Kashmir, Shalimar Srinagar, pp. 58.

Anonymous, 1992. The wealth of India. Raw materials vol. 2 pp. 374-375, CSIR, New Delhi.

Anonymous, 2011. Chestnut (Castanea sativa. Mill), pp. 63-65. In: Temperate Fruits Packages of Practices. Directorate of extension education SKUAST-Kashmir, Shalimar.

Celik, H., Serdar, U. and Beyhan, N. 2009. Studies on chestnut grafting with hand and hand manual grafting units. Acta Horticulturae 815: 205-209.

Ferrini, F. 1993. Conoscenze e problem sulla propagaione vegetative del castago. Rivista di Frutticoltura 12: 43-48.

Gautam, S.R., Khatiwada, P.P., Thapa, M.P., Neupane, G. and Shrestha, C.P. 1991. Preliminary observation on plant propagation of fruit and nuts at Pakhribas Agriculture Centre. PAC working paper Pakhribas Agriculture Centre 24: 19.

Hartmann, H.T. and Kester, D.E. 1968. Plant propagation principles and practices. Prentice Hall of India pvt. Ltd, New Delhi, pp.702. 
Hartmann, H.T., Kester, D.E. and Davies, F.J. 1990. Plant propagation principles and practices. Prentice Hall of India pvt. Ltd, New Delhi, pp. 647.

Hartmann, H.T., Kester, D.E. and Davies, F.J. 1997. Plant propagation principles and practices. Prentice Hall of India pvt. Ltd, New Delhi, pp. 662.

Howard, B.H. 1979. Chip budding fruit and ornamental trees. Proceeding International Plant Propagation Society, 27: 357-364.

Janick, J. and Moore, J.N. 1975. Advance in fruit breeding. In: [Eds. J. Janick and J.N. Moore], Indiana.

Joolka, N.K., Rindhe, A.B. and Sharma, M.K. 2001. Standardize grafting technique in pecan. Indian Journal of Horticulture 58: 3-4.

Ozturk, A. and Serdar, U. 2011. Effects of different nursery conditions on the plant development and some leaf characteristics in Chestnut (Castanea sativa Hill.). Australian Journal of Crop Science 5(10): 1218-1223.

Pathak, R.K. and R.P. Srivastava. 1975. Studies on the vegetative propagation of walnut. Preliminary observation on grafts. Progressive Horticulture 3: 6568.

Saylu, A. 1984. Chestnut growing and specialities. A taurk Hort. Res. Inst. Publ. No.59. Yalova (In Turkish).

Serdar, U. and Demirsoy, H. 2010. Graft compatibility in some Turkish chestnut genotypes (Castanea sativa. Mill.). Acta Horticulturae, 866: 285-287.

Serdar, U. and Macit. I. 2010. New advances in chestnut growing in the Black sea region. Acta Horticulturae, 866: 303308.

Serdar, U. and Soylu, A. 1999. Selection of chestnut (C. sativa Mill.) in Samsun vicinity. Acta Horticulturae, 494: 327332.

Serdar, U. and Soylu, A. 2005. The effect of grafting time and methods on chestnut nursery tree production. Acta Horticulturae, 693: 187-194.

Stritzke, S. 1959. The formation of union in different varieties rootstock combinations following the grafting of walnut. Arch. Gartenb 7: 61-68.

Warmund, M.R. and Coggeshall, M.V. 2009. Chip budding of AU-supper Chinese chestnut scion on AU-cropper and qing seedling rootstocks. Acta Horticulturae 844: 115-117.

Woodroof, J.G. 1979. Tree nuts. A publishing co. Inc., Westport Connecticut, pp. 230264.

\section{How to cite this article:}

Sharbat Hussain, Rifat Bhat, M.M. Mir, Sheeraz A. Wani, Rahila Shameem and Mohit Husain. 2018. Effect of Different Budding Methods and Timings on Budding Success of Chestnut (Castanea sativa, Mill). Int.J.Curr.Microbiol.App.Sci. 7(02): 1643-1649.

doi: https://doi.org/10.20546/ijcmas.2018.702.198 